Saudi Journal of Business and Management Studies Abbreviated Key Title: Saudi I Bus Manag Stud ISSN 2415-6663 (Print) |ISSN 2415-6671 (Online) Scholars Middle East Publishers, Dubai, United Arab Emirates Journal homepage: https://saudijournals.com/sjbms

Original Research Article

\title{
The Influence of Premium Income and Claim Loads on Profit in Retired Management Institutions in 2013 until 2018 (PT Taspen (PERSERO), PT Asabri (PERSERO) dan BPJS Ketenagakerjaan)
}

\author{
Muhammad Agustian Firnando*, Jan Hoesada
}

Mercu Buana University Jakarta

DOI: $10.36348 /$ sjbms.2020.v05i03.005

| Received: 14.02 .2020 | Accepted: 01.03 .2020 | Published: 18.03 .2020

*Corresponding author: Muhammad Agustian Firnando

\section{Abstract}

Appreciation for services provided by institutions based on premiums that have been paid in accordance with the provisions or regulations of the institution. Welfare after entering the Retirement Age Limit is the expectation of the participants. Social insurance as an obligation for every citizen, where citizens have assumed the tasks they have experienced and are required to get insurance in old age. In Indonesia there are various pension management institutions in the form of SOEs and the Ketenagakerjaan Guarantee Agency. BUMN pension managers are managed by PT Taspen (PERSERO) with ASN participants, State Officials, Veterans and Non-ASN, and PT Asabri (PERSERO) with TNI and POLRI participants. Whereas in the form of a Board, it is managed by BPJS Ketenagakerjaan with participants from all BUMN and private workers. Managing agency. This study is useful to know the Effect of Premium Income and Claims Expense on Company Profit at Pension Management Institutions (PT Taspen (PERSERO), PT Asabri (PERSERO) and BPJS Ketenagakerjaan). Regression research method with a quantitative approach by collecting data by taking data in the Annual Report Audited in the companies PT Taspen (PERSERO), PT Asabri (PERSERO) and BPJS Ketenagakerjaan in 2013 to 2018. Hypothesis testing results are as much as 49.3\% independent variable influences the profit of PT Taspen (PERSERO), 98.6\% independent variable influences the profit of PT Asabri (PERSERO) and 34.9\% independent variable influences the profit of BPJS Ketenagakerjaan.

Keywords: Premium Income, Claim Expense, Company Profit and Annual Report.

Copyright @ 2020: This is an open-access article distributed under the terms of the Creative Commons Attribution license which permits unrestricted use, distribution, and reproduction in any medium for non-commercial use (NonCommercial, or CC-BY-NC) provided the original author and source are credited.

\section{INTRODUCTION}

Social insurance as an obligation for every citizen, where citizens have assumed the tasks they have experienced and are required to get insurance in old age. Pension institutions are assigned by the government to manage social insurance in Indonesia. There are a number of pension fund managers in Indonesia engaged in state-owned and private companies. The social insurance managed by this pension institution has a diverse program of products.

I work at PT Taspen (Persero), a state-owned company engaged in insurance that manages a variety of social security programs. The programs run by these three companies have the same program from participants who make premium contributions within a certain period of time to make claims when they are due or when the participant experiences an event. Premium contributions paid by participants will be included in premium income. Investment limitations made by management caused by the existence of regulations or government regulations that govern insurance companies to invest. The limited investment made by the insurance company causes the insurance company to not get the maximum profit.

Participants who have paid premium contributions will get the rights and obligations for participants to submit claims. Claims can be submitted by participants when a participant is due or a participant experiences an event. Claims submitted by participants must be monitored by pension institutions to allocate 
cash flow to be paid to participants. The insurance company arranges the program it manages for participants who will submit claims. The insurance company is obliged and ready to undertake if the participant will submit a claim when due or experiences. Based on the theory states that if operating expenses and claims expenses increase, the company's profit decreases and vice versa if the operational and claims expenses decrease, the company's profit increases. These two things greatly affect the company's profit because the difference is more or less revenue with expenses greatly affect the company's profit. The insurance company must maintain a healthy consideration between the amount of premium income and the burden of claims. The size of the premium income can affect company profits.

Claims paid by insurance companies will experience a significant difference depending on customer satisfaction. Customer satisfaction is the most important in satisfying customers by giving loyalty to customers who will benefit the company. Profit as an increase in the wealth of those concerned as capital minus costs. Meanwhile, non-profit is not looking for profits that have social and social purposes. In my research there are companies that generate profits and surpluses.

Social insurance as an obligation for every citizen, where citizens have assumed the tasks they have experienced and are required to get insurance in old age. In Indonesia there are managers of pension institutions. These pension institutions are assigned by the government to manage social insurance. There are pension fund managers in the BUMN and private sector. Social Insurance managed by this pension institution has the same program. The author takes 3 population pension management institutions SOEs and Social Security Agency in Indonesia.

Pension is an award for services provided by the institution in accordance with the provisions or regulations of the institution. The author examines the titled Effect of Premium Income and Climate Expense on Profit at Pension Institutions in 2013 s.d. 2018 (PT Taspen (Persero), PT Asabri (Persero) and BPJS Ketenagakerjaan).

\section{LITERATURE REVIEW \\ Premium Income}

Revenue is the exit of goods and services from the institution to the customer and the results of the product release will produce goods and services. Retirement is a condition where a person no longer works due to the completion of his tenure. Pension types can be divided into two, namely:

\section{Definite Benefits}

Defined Benefit is a pension plan that will be paid when participants reach the age limit based on a formula.

\section{Defined Contribution}

Definite Contribution is a pension program that is added with pension benefits in the form of development proceeds.

\section{Claim Expense}

Claim Expenses represent benefits received by participants in the form of cash and compensation for contributions that have been provided to the insurer in the form of a policy.

\section{Company Profit}

Company profit is the company's main goal to gain profit from activities. There are 2 types of profit consisting of gross profit and net profit.

\section{Pension Funds}

Pension funds are companies that manage guarantees for citizens consisting of various programs to participants when they reach retirement age, which is regulated by various government policies and regulations.

\section{Social Security Program}

Social programs are guarantees given by the state to citizens to prosper the people for their service marks. The social security program managed by pension management institutions consists of 4:

\section{Old Age Savings}

Old Age Savings program is a program that is given to participants if a participant experiences a Pension Death (PMK) incident in the form of cash or a bank.

\section{Retire}

Pension Plan is a program that is received by participants if the participant experiences a Pension Death (PMK) incident in the form of monthly income for the services provided.

\section{Work Accident Insurance}

Work Accident Insurance is a program that is received by participants in the form of care, compensation and disability benefits if they are at risk of work accident.

\section{Death Guarantee}

Death Guarantee is a program received by the heirs in the form of death compensation for the death of the participant.

\section{HYPOTHESIS}

There are several hypotheses in this study, namely:

Ho1 : Ho1: There is no significant effect between premium income versus profit.

Ha1 : There is a significant influence between premium income on earnings.

Ho2 : There is no significant influence between the burden of claims on earnings.

$\mathrm{Ha} 2$ : There is a significant influence between the burden of claims on earnings. 
Ho3 : There is no significant effect simultaneously (together) between premium income and claim expense on profit.

Ha3 : There is a significant simultaneous effect (together) between income premiums and claim expense on profits.

\section{RESEARCH METHODS}

The research method uses regression with quantitative approaches and statistical testing methods. The research year used was 2013 to 2018 The variables used were independent and dependent variables.

The population is the entire object under study consisting of 3 pension management institutions in Indonesia in 2013 s.d. 2018 consisted of PT Taspen (PERSERO), PT Asabri (PERSERO) and BPJS Ketenagakerjaan. The research sample was taken over 6 years of data namely from the Audited Financial Statements and Interviews. Research by observing research objects based on audited financial statements and interviews.

\section{RESULTS}

Descriptive Research Object

1. PT Taspen (PERSERO)

PT Taspen (PERSERO) manages ENT, JKK, JKM and Pension insurance programs with PNS participants, State Officials, Veterans, PPPK and Non ASN.

2. PT Asabri (PERSERO)

PT Asabri (PERSERO manages the ENT, JKK, JKM and Pension insurance programs with the TNI, POLRI and PNS civil servant participants.

3. BPJS Ketenagakerjaan

BPJS Ketenagakerjaan manages JHT, JKK, JKM and Pension programs with participants from all BUMN and private companies.

\section{Normality Test}

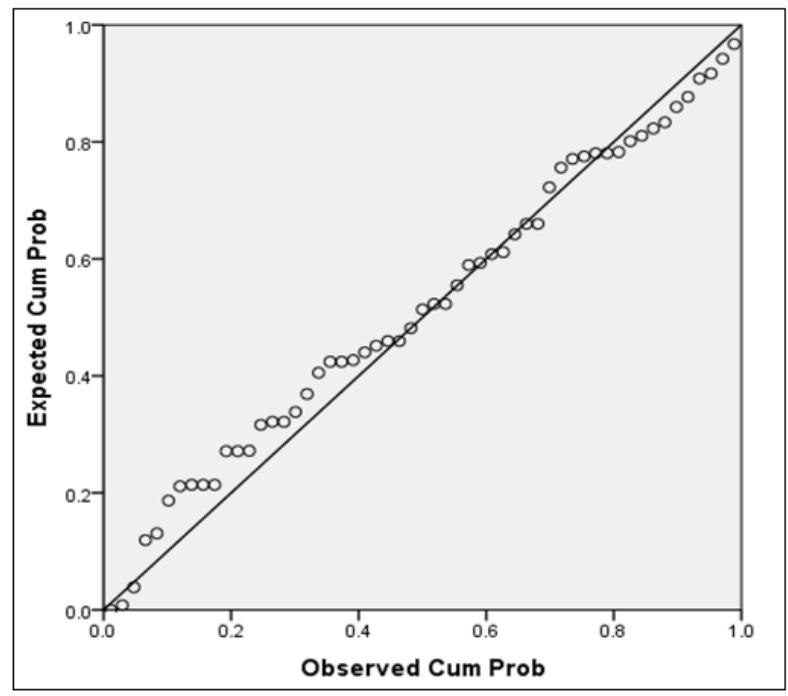

Based on the probability plot of the company's profits are residual plots around the straight line. To prove that normal residuals were tested by Kolmogorov Smirnov test statistics. Testing the normality assumption of the BM model with the Kolmogorov Smirnov test statistic 0.279 with a probability of 0.200 indicates that the probability of $\mathrm{HO}$ is accepted. Residual Influence of Premium Income and Claims Expense on Company Profit is stated in normal distribution so that the assumption of normality is fulfilled.

\section{Multicollinearity Test}

Table-1: Multicollinearity Test

\begin{tabular}{|l|c|}
\hline Variable & VIF \\
\hline Premium Income & 6,422 \\
\hline Claim Expense & 6,422 \\
\hline
\end{tabular}

(Source: Data processed with SPSS 20)
Testing the effect simultaneously on the company PT Taspen (PERSERO) with an F value of 1.461 and a probability of 0.361 .

$\mathrm{P}$ value $=0.361>0.05$, that means $\mathrm{H} 0$ is accepted, H1 is rejected. There is a linear relationship between premium income and claim expense. The conclusion from the results is not significant. Where the dependent variable (income and climate) does not affect earnings at a significance level of $5 \%$. And the model has no statistical significance of $95 \%$.

\section{HYPOTHESIS TEST}

The significance test of Influence of Premium Income and Expense Claims on Profit is intended to know the effect simultaneously.

\section{Simultaneous Testing of Significance} F Test PT Taspen (PERSERO) 
Table-2: F Test PT Taspen (PERSERO)

\begin{tabular}{|l|l|l|l|l|l|}
\hline Model & Sum of Squares & Df & Mean Square & F & Sig. \\
\hline Regression & 3685117.982 & 2 & 1842558.991 & 1.461 & $.361^{\mathrm{a}}$ \\
\hline Residual & 3782723.291 & 3 & 1260907.764 & & \\
\hline Total & 7467841.274 & 5 & & & \\
\hline
\end{tabular}

Testing the effect simultaneously on the company PT Taspen (PERSERO) with an F value of 1.461 and a probability of 0.361 .

$\mathrm{P}$ value $=0.361>0.05$, that means $\mathrm{H} 0$ is accepted, H1 is rejected. There is a linear relationship between premium income and claim expense. The conclusion from the results is not significant. Where the dependent variable (income and climate) does not affect earnings at a significance level of $5 \%$. And the model has no statistical significance of $95 \%$.

F Test PT Asabri (PERSERO)

Table-3: F Test PT Asabri (PERSERO)

\begin{tabular}{|l|l|l|l|l|c|}
\hline Model & Sum of Squares & df & Mean Square & F & Sig. \\
\hline Regression & 440984.818 & 2 & 220492.409 & 103.212 & $.002^{\mathrm{a}}$ \\
\hline Residual & 6408.910 & 3 & 2136.303 & & \\
\hline Total & 447393.727 & 5 & & & \\
\hline
\end{tabular}

Testing the effect simultaneously on the company PT Asabri (PERSERO) with a calculated F value of 103.212 and a probability of 0.002 .

$\mathrm{P}$ value $=0.002<0.05$, it means $\mathrm{H} 0$ is rejected, $\mathrm{H} 1$ is accepted. There is a linear relationship between premium income and claim expense. So, the conclusion of the result is significant. Where the dependent variable (income and climate) affects earnings at a significance level of 5\%. And the statistical significance model is $95 \%$.

F Test BPJS Ketenagakerjaan

Table-4: F Test PT Asabri (PERSERO)

\begin{tabular}{|l|l|l|l|l|c|}
\hline Model & Sum of Squares & df & Mean Square & F & Sig. \\
\hline Regression & 440984.818 & 2 & 220492.409 & 103.212 & $.002^{\mathrm{a}}$ \\
\hline Residual & 6408.910 & 3 & 2136.303 & & \\
\hline Total & 447393.727 & 5 & & & \\
\hline
\end{tabular}

Testing the effect simultaneously on BPJS Ketenagakerjaan companies with an $\mathrm{F}$ value of 0.803 and a probability of 0.526 .

Value of $\mathrm{P}=0.526>0.05$, that means $\mathrm{H} 0$ is accepted, H1 is rejected. There is a linear relationship between income and climate. So, the conclusions from the results are not significant. Where the dependent variable (income and climate) does not affect earnings at a significance level of $5 \%$. And the model has no statistical significance of $95 \%$.

Partial Significance Test (Test T)

Test T PT Taspen (PERSERO)

Table- 5: T Test PT Taspen (PERSERO)

\begin{tabular}{|l|l|l|l|l|l|}
\hline \multirow{2}{*}{ Model } & \multicolumn{2}{|l|}{ Unstandardized Coefficients } & Standardized Coefficients & \multirow{2}{*}{ t } & \multirow{2}{*}{ Sig. } \\
\cline { 2 - 6 } & B & Std. Error & Beta & & \\
\hline Constant) & 6428.944 & 3170.189 & & 2.028 & .136 \\
\hline Premium Income & -.754 & .449 & -.693 & -1.680 & .191 \\
\hline Claim Expense & -.028 & .167 & -.070 & -.169 & .876 \\
\hline
\end{tabular}

Testing Individual Parameters

The coefficient table shows the individual test ( $\mathrm{t}$ test).

$$
\hat{Y}=\hat{\beta}_{0}+\hat{\beta}_{1} x_{1}+\hat{\beta}_{2} x_{2}+\hat{\beta}_{3} x_{3}
$$

$B 0=6428,944$ (constant)

Value of $\mathrm{P}=0.136>0.05$, that means $\mathrm{H} 0$ is accepted, $\mathrm{H} 1$ is rejected. So, the conclusions from the results are not significant.

$ß 1=-0,754$ (premium income)
Value of $\mathrm{P}=0.191>0.05$, that means H0 is accepted, $\mathrm{H} 1$ is rejected. So, the conclusions from the results are not significant.

$B 2=-0,028$ (claims)

Value of $\mathrm{P}=0.876>0.05$, that means $\mathrm{H} 0$ is accepted, $\mathrm{H} 1$ is rejected. So, the conclusions from the results are not significant.

Test T PT Asabri (PERSERO) 
Table-6: T Test PT Asabri (PERSERO)

\begin{tabular}{|l|l|l|l|l|l|}
\hline \multirow{2}{*}{ Model } & \multicolumn{2}{|c|}{ Unstandardized Coefficients } & Standardized Coefficients & t & Sig. \\
\cline { 2 - 7 } & $\mathbf{B}$ & Std. Error & Beta & & \\
\hline Constant) & -357.494 & 163.377 & & -2.188 & .116 \\
\hline Premium Income & 2.511 & .577 & -1.701 & -4.351 & .022 \\
\hline Claim Expense & 3.561 & .531 & 2.620 & 6.703 & .007 \\
\hline
\end{tabular}

Testing Individual Parameters

The coefficient table shows the individual test (t test).

$$
\hat{Y}=\hat{\beta}_{0}+\hat{\beta}_{1} x_{1}+\hat{\beta}_{2} x_{2}+\hat{\beta}_{3} x_{3}
$$

$B 0=-357,494$ (constant)

Value of $\mathrm{P}=0.116>0.05$, that means $\mathrm{H} 0$ is accepted, $\mathrm{H} 1$ is rejected. So, the conclusions from the results are not significant.

$ß 1=-2,511$ (income)
$\mathrm{P}$ value $=0.022<0.05$, it means $\mathrm{H} 0$ is rejected, $\mathrm{H} 1$ is accepted. So, the conclusion of the result is significant. $\beta 2=3,561$ (claims)

Value of $\mathrm{P}=0.007<0.05$, that means $\mathrm{H} 0$ is rejected, $\mathrm{H} 1$ is accepted. So, the conclusion of the result is significant.

Test T BPJS Ketenagakerjaan

Table-7: T Test BPJS Ketenagakerjaan

\begin{tabular}{|l|l|l|l|l|l|}
\hline \multirow{2}{*}{ Model } & \multicolumn{2}{|c|}{ Unstandardized Coefficients } & Standardized Coefficients & \multirow{2}{*}{ S } & \multirow{2}{*}{ Sig. } \\
\cline { 2 - 4 } & B & Std. Error & Beta & & \\
\hline Constant) & -357.494 & 163.377 & & -2.188 & .116 \\
\hline Premium Income & 2.511 & .577 & -1.701 & -4.351 & .022 \\
\hline Claim Expense & 3.561 & .531 & 2.620 & 6.703 & .007 \\
\hline
\end{tabular}

Testing Individual Parameters

The coefficient table shows the individual test (t test).

$$
\hat{Y}=\hat{\beta}_{0}+\hat{\beta}_{1} x_{1}+\hat{\beta}_{2} x_{2}+\hat{\beta}_{3} x_{3}
$$

$B 0=-670,778$ (constant)

because the value of $\mathrm{P}=0.701<0.05$, it means $\mathrm{H} 0$ is accepted, H1 is rejected. So, the conclusion from the result is not significant.

$\beta 1=0.124$ (premium income)

Value of $\mathrm{P}=0.664>0.05$, that means H0 is accepted, $\mathrm{H} 1$ is rejected. So, the conclusion from the result is not significant.

\section{$\beta 2=0.471$ (claim)}

Value of $\mathrm{P}=0.627>0.05$, that means $\mathrm{H} 0$ is accepted, $\mathrm{H} 1$ is rejected. So, the conclusion from the result is not significant.

\section{Effect of Premium Income on Company Profit}

The results showed the effect of premium income on company profits, among others, as follows:

1. There was $49.3 \%$ variance of PT Taspen (Persero)'s 2013 profit 2018 is explained by premium income as the dependent variable, and the remaining 50.7\% other variables. The results of this study are in accordance with Hanifaturrosida [1] $T$ Test results or partially variable premiums, claims and under writing have a negative and significant effect on profitability while investment has a positive and significant effect on the profitability of Islamic life insurance companies.

2. There is a $98.6 \%$ variance of PT Asabri (Persero) 2013-2018 profit explained by premium income as the dependent variable, and the remaining $1.4 \%$ is explained by other variables. The results of this study are consistent with the study of Sofyan Marwansyah et al., [2] Investment results and premium income have a significant relationship to earnings, a positive value of 0.657 and 0.737 means a strong and unidirectional relationship while the claim burden has a significant relationship to earnings, a negative value of -0.786 means the relationship is strong and opposite direction, simultaneously (together) shows that investment returns, premium income, claims expenses have a significant relationship to profits, and are positive at 0.881 .

3. There is $34.9 \%$ variance of BPJS Ketenagakerjaan earnings in 2013-2018 explained by premium income as the dependent variable, and the remaining $65.1 \%$ is explained by other variables. The results of the study are in accordance with Hanifaturrosida [1] Test Results $\mathrm{T}$ Test or partially premium variables, claims and under writing have a negative and significant effect on profitability while investment has a positive and significant effect on the profitability of Islamic life insurance companies..

\section{The effect of claim expenses on earnings}

The effect of claim expenses on company profits is as follows:

1. There was $49.3 \%$ variance of PT Taspen (Persero)'s 2013 profit 2018 is explained by the burden of claims as the dependent variable, and the remaining $50.7 \%$ is explained by other variables.

2. There is a $98.6 \%$ variance of PT Asabri (Persero) 2013-2018 profit explained by the burden of claims as the dependent variable, 
and the remaining $1.4 \%$ is explained by other variables.

3. There is $34.9 \%$ variance of BPJS Ketenagakerjaan earnings in 2013-2018 explained by the burden of claims as the dependent variable, and the remaining $65.1 \%$ is explained by other variables.

\section{Data Analysis}

Claim expenses are expenses incurred by the company to provide protection to the insured party by compensating for costs according to the insurance policy agreement. The premium income data can be seen from the graph as follows:

PT Taspen (PERSERO)

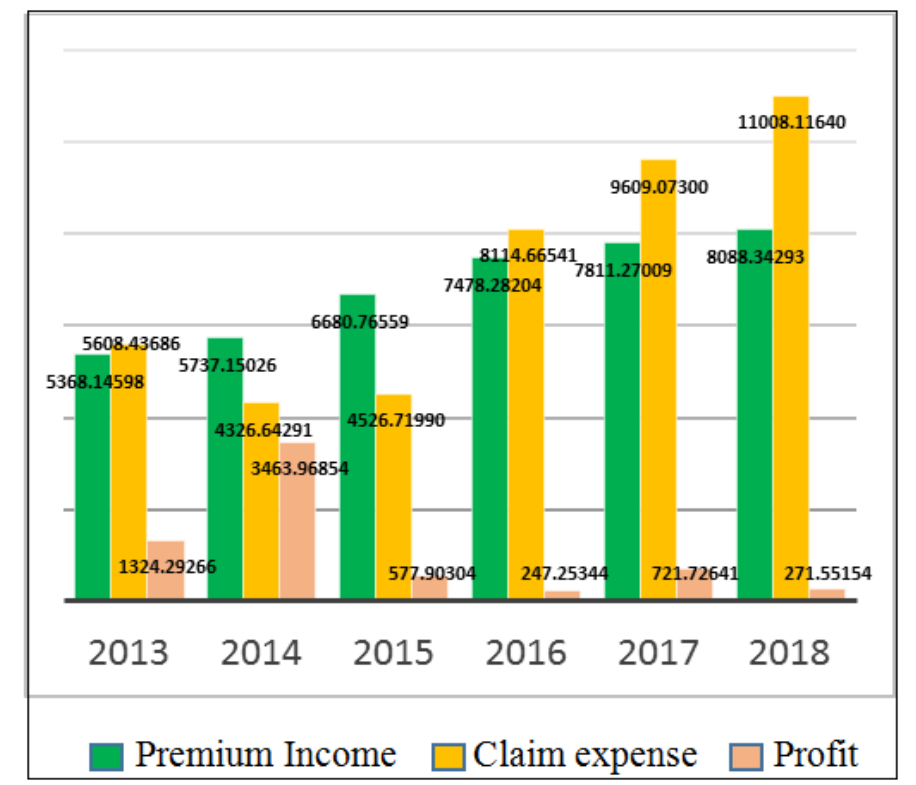

Graph-1: Premium income, claim expense and profit PT Taspen (PERSERO)

\section{Graphical Data Analysis}

1. Premium income from 2013 until 2018 increased.

2. In 2014 and 2015 the claim burden decreased due to the extension of the Retirement Age Limit (BUP) of civil servants from 56 years to 58 years.

3. An increase in claims expense from 2016 to 2018 because civil servants have entered the Pension
Age Limit (BUP) age 58 years and pro-active PT Taspen (PERSERO) services to participants in the form of Automatic Claim Services will enter the Pension Age Limit (BUP) without having to come to the office of PT Taspen (PERSERO).

PT Asabri (PERSERO)

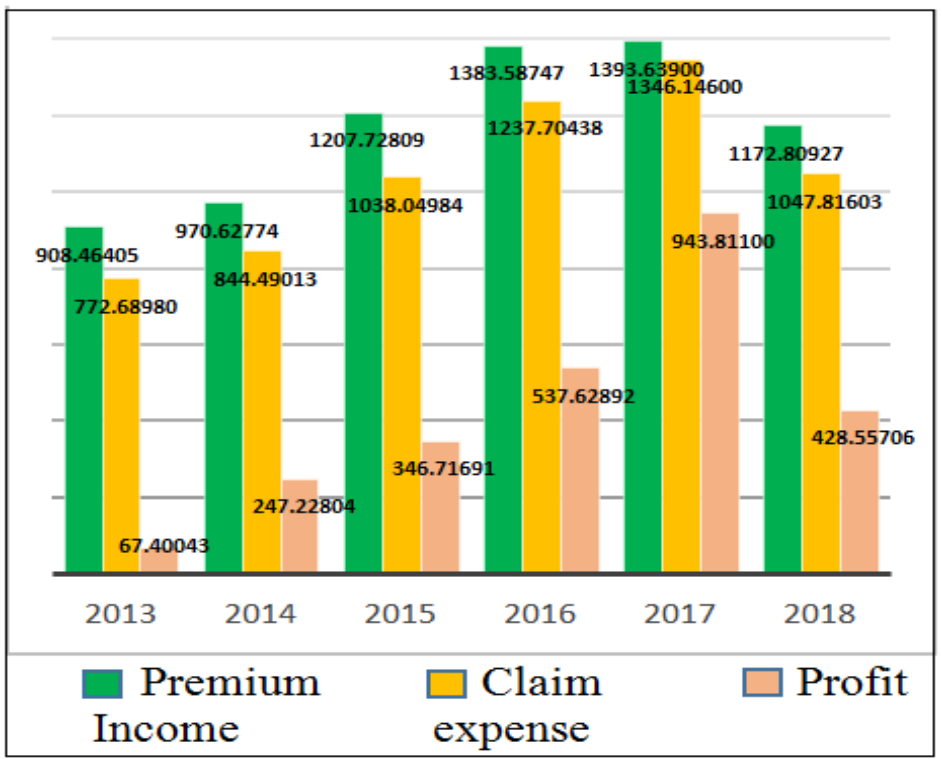

Graph-2: Premium income, claim expense and profit PT Asabri (PERSERO) 


\section{Graphical Data Analysis}

1. Premium income and claim expenses have increased from 2013 to 2018.

2. Comparison between premium income is greater than claims from participants. The importance of pro-active outreach and services to participants so that participants know the rights and obligations for participants to various companies

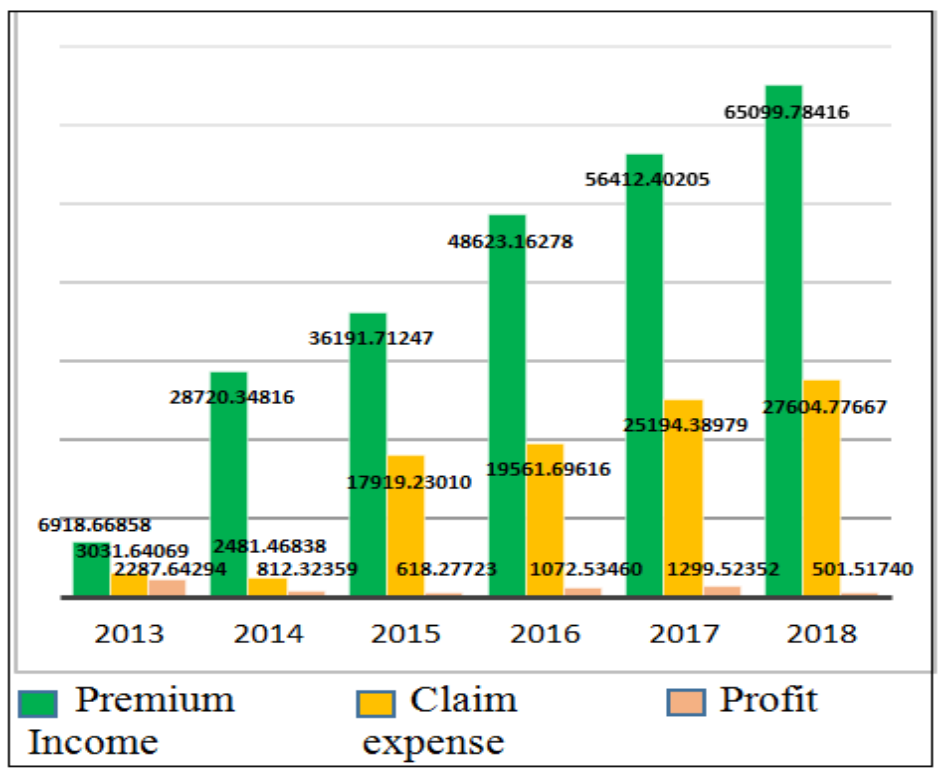

Graph-3: Premium income, claim expense and profit BPJS Ketenagakerjaan

\section{Graphical Data Analysis}

1. Premium income has always significantly increased from 2013 to 2018 which is because many companies will be aware of the importance of social security.

2. Comparison between premium income is greater than claims from participants. The importance of pro-active outreach and services to participants so that participants know the rights and obligations for participants to various companies.

\section{CONCLUSIONS}

Based on the problem formulation, hypothesis testing and discussion the following conclusions can be drawn:

1. Influence of premium income on company profits on pension agency managers, among others, as follows:

a. $49.3 \%$ variance of PT Taspen (Persero) 's 2013 profit 2018 is explained by premium income as the dependent variable, and $50.7 \%$ is explained by other variables.

b. $98.6 \%$ of PT Asabri (Persero) 2013-2018 profit is explained by premium income as the dependent variable, and $1.4 \%$ is explained by other variables.

c. $34.9 \%$ of BPJS Ketenagakerjaan profit in 2013-2018 is explained by premium income as the dependent variable, and $65.1 \%$ is explained by other variables.
2. The influence of the burden of claims on corporate profits on the management of pension institutions include the following:

a. $49.3 \%$ variance of PT Taspen (Persero) 's 2013 profit 2018 is explained by the burden of claims as the dependent variable, and $50.7 \%$ is explained by other variables.

b. $98.6 \%$ of PT Asabri (Persero) 2013-2018 profit is explained by the burden of claims as the dependent variable, and $1.4 \%$ is explained by other variables.

c. As much as $34.9 \%$ of the variance of BPJS Ketenagakerjaan earnings in 2013-2018 is explained by the burden of claims as the dependent variable, and $65.1 \%$ is explained by other variables.

3. Based on data on the percentage of the influence of other variables that affect the increase in corporate profits so that if the burden of claims increases, then other variable factors can determine the increase in corporate profits.

\section{RECOMMENDATION}

In connection with this study, the authors suggest the following:

1. For further researchers

This study uses a population of 3 insurance companies with similar programs, so that future research adds research objects and independent variables as a comparison.

2. For management 
For management it is necessary to increase other variable factors because the premium income is smaller than the claim burden from the participants so that it affects the company's profit.

\section{REFERENCES}

1. Najmiah, N. (2019). Analisis hasil investasi, pendapatan premi, dan beban klaim terhadap laba perasuransian di indonesia (Studi Kasus pada
Perusahaan Asuransi di Indonesia Tahun 2012. 2016) (Doctoral dissertation, Universitas Mercu Buana Yogyakarta).

2. Marwansyah, S., \& Utami, A. N. (2017). Analisis hasil investasi, Pendapatan Premi, dan Beban klaim terhadap laba perusahaan perasuransian di Indonesia. Jurnal Akuntansi, Ekonomi dan Manajemen Bisnis, 5(2), 213-221. 